\title{
Teaching Managerial Economics In MBA Programs: A Survey Of AACSB Colleges
}

Bharat Kolluri, (E-mail: Kolluri@mail.hartford.edu), University of Hartford Rao Singamsett, (E-mail: singamset@mail.hartford.edu), University of Hartford,

\begin{abstract}
There is a significant variation in the managerial economics course in terms of the prerequisites, contents and delivery in the MBA programs of AACSB institutions. In order to get detailed information on these aspects, we conducted a survey of 275 AACSB institutions and reported the results. Briefly, the survey indicates that majority of the programs require principles of economics and business statistics as prerequisites among other things. Based on the survey results, the paper strongly recommends a two course sequence in economics, an introduction to economics as a prerequisite and a managerial economics course in the core of the MBA program.
\end{abstract}

\section{SECTION I: INTRODUCTION}

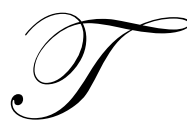

he purpose of this article is to identify suitable topics in managerial economics course for graduate students in MBA programs. This program of study at some universities like the University of Hartford has undergone some changes in that they used to have one course in calculus and another combined course in macro and microeconomics as prerequisites before the students take managerial economics course and now the new MBA curriculum does not require principles of economics and calculus as prerequisites. Calculus prerequisite was dropped mainly for the reason that the concepts like marginal value and elasticity could be easily introduced without the use of the concept of derivative. Further, calculus-based techniques may turn off the students away from the more important real use and interpretation of business data, analysis and decision-making. The combined (micro and macro) introductory course in economics was dropped for a number of reasons. First, to facilitate introduction of higher level innovative courses such as Management of Technology and Customer Interfaces. Second, to offer a combined introductory and managerial economics course in order to keep total required credits of the MBA program the same. Third, to reduce the traditional institutional and theoretical topics in favor of economic applications in managerial decision-making process. These decisions posed a challenge and an opportunity to redesign the MBA course, managerial economics, if necessary by introducing a combined micro, macro course again. The traditional managerial economics course includes microeconomics topics and some topics in industrial organization, demand estimation, forecasting GDP and some international trade concepts. The new managerial economics needs to include rudiments of macroeconomics and it is our task to integrate macro and microeconomics principles together with the core of managerial economics in a single or a sequence of two courses. Such a blend of topics, including principles, would give the students a necessary foundation and decision - making skills in the program.

We conducted a survey of 275 AACSB institutions comparable* to the University of Hartford. Out of the 100 institutions from which we got responses, seventy two are semester based, fifteen are non-semester based, mostly quarter type, and the remaining 13 do not offer the traditional managerial economics course. We classified the twosemester-a-year based institutions as Group 1 and the non-semester based as Group 2. Although the Business School at the University of Hartford is AACSB accredited we did not include it in the survey to avoid any possible bias in the results.

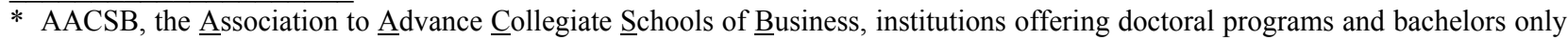
programs are excluded from our survey as they are deemed to be non comparable to the University of Hartford. A list of such institutions was prepared from AACSB Membership Directory, 2000. Altogether 275 survey questionnaires (see Appendix B) were mailed with a letter (see Appendix A) to the Deans of the selected institutions. As of the end of May, 2001 we received 100 responses.
} 
Briefly, in section II, Table 1 presents the pre-requisites for managerial economics for Group 1 and Group 2 institutions. Table 2 presents approximate average weights (percentages) given to introduction to micro, macro and managerial economics. Further, we examine the distribution of these weights among the institutions based on the survey results, and our own judgment. On the basis of this information, we present an appropriate outline of topics in managerial economics course in a general MBA program.

In section III, we present alternative non-calculus methods of solutions and interpretation in dealing with traditionally calculus based topics such as optimization, marginal values and elasticity. Finally in section IV, we present summary and concluding remarks.

\section{SECTION II: SURVEY RESULTS}

As the main purpose of this paper is to examine the managerial economics course in the MBA programs and its contents offered at other AACSB institutions, we present a survey analysis of Groups 1 and 2 institutions.

We present in Table 1, Mathematics, Statistics and Economics courses required as prerequisites in the MBA programs.

Table 1: Prerequisites for Managerial Economics Course

\begin{tabular}{|c|c|c|}
\hline Pre-requisite & \multicolumn{2}{|c|}{ Percent of Institutions } \\
\hline & Group 1 & 7 \\
\hline Algebra & 25 & 7 \\
\hline Pre-calculus & 20 & 47 \\
\hline Calculus & 41 & 27 \\
\hline Business Statistics & 52 & 33 \\
\hline Microeconomics & 59 & 3 \\
\hline Macroeconomics & 55 & 33 \\
\hline Both Micro \& Macro & 53 & 20 \\
\hline No prerequisites & 19 & \\
\hline
\end{tabular}

Group 1 are semester based and Group 2 are quarter based. Although results of Group 2 are provided, we caution the reader not to give importance since it constitutes a very small sample.

Table 1 shows that more than 50 percent of institutions require either macro or micro economic courses or business statistics course as prerequisites for the managerial economics course in their MBA program in Group 1. In Group 2 such percentage varies from 20 to 33 .

Both micro and macro economics are required as prerequisites by 53\% of the Group 1 institutions, but by only $3 \%$ of Group 2 institutions.

Calculus is still required by more than $40 \%$ of the institutions both in Group 1 and Group 2. It is evident from these survey results that the majority of the institutions require both macro and microeconomics as prerequisites and therefore we recommend an introductory combined macro and micro economics course as a prerequisite for MBA programs.

Table 2 presents the distribution of macro, micro and managerial economics components as percent coverage in Group 1 and Group 2 institutions. 
Table 2: Distribution of institutions according to percentage coverage of Micro, Macro and Managerial Economics contents in General MBA Managerial Economics Course

\begin{tabular}{|c|c|c|c|c|c|c|}
\hline \multirow{2}{*}{$\begin{array}{c}\text { Percent } \\
\text { Coverage }\end{array}$} & \multicolumn{2}{|c|}{ Macroeconomics } & \multicolumn{2}{|c|}{ Microeconomics } & \multicolumn{2}{|c|}{ Managerial Economics } \\
\hline & Group 1 & Group 2 & Group 1 & Group 2 & Group 1 & Group 2 \\
\hline $0-20$ & 52 & 12 & 29 & 7 & 10 & 1 \\
\hline $21-40$ & 11 & 1 & 24 & 4 & 12 & 2 \\
\hline $41-60$ & 4 & 0 & 10 & 3 & 20 & 3 \\
\hline $61-80$ & 0 & 1 & 5 & 0 & 16 & 3 \\
\hline $81-100$ & 2 & 0 & 1 & 0 & 11 & 5 \\
\hline Total & 69* & $14 *$ & 69* & 14* & 69* & $14 *$ \\
\hline $\begin{array}{c}\text { Average \% } \\
\text { coverage }\end{array}$ & 18 & 16 & 28 & 24 & 52 & 63 \\
\hline
\end{tabular}

*Three institutions in Group 1 and one institution in Group 2 did not respond to this question.

Group 1 are semester based and Group 2 are quarter based.

On average, macro, micro and managerial economics components constitute $18 \%, 28 \%$ and $52 \%$ respectively, of the course in Group 1 institutions. These percentages respectively are 16, 24 and 63 in Group 2 institutions. For instance, the managerial economics course offered at the University of Hartford is similar to Group 1 coverage pattern. That is, we cover about $20 \%$ macro, $30 \%$ micro and the remaining $50 \%$ topics in managerial economics. It is to be noted that the results in Table 2 do not distinguish the institutions that require prerequisites from those that do not. It is obvious that although the average coverage of macro, micro and managerial components appears to be the same in all the Group 1 institutions, quality and depth of instruction tend to be lower in institutions with no prerequisites.

Table 3 describes the total required economics courses ( prerequisites and managerial economics ) in the MBA programs of the AACSB institutions. Our survey results clearly show that a majority of the institutions, $65 \%$, in Group 1 , require more than one economics course. This is another piece of evidence in favor of our earlier recommendation to have an introductory economics course as a prerequisite to any MBA program.

Table 3: Total Required Economics courses (Prerequisites + Managerial Economics) in The MBA Programs of the Survey

\begin{tabular}{|c|c|c|}
\hline No. of Economic courses & Group 1 & Group 2 \\
\hline One or less & $35 \%$ & $67 \%$ \\
\hline More than one & $65 \%$ & $33 \%$ \\
\hline Beyond Managerial Economics & $22 \%$ & $47 \%$ \\
\hline
\end{tabular}

Based on our survey we presented the distribution of important topics in managerial economics course such as quantitative applications, cases and global and trade issues in Table 4. This evidence is presented in order to identify the importance given to these topics in managerial economics in various institutions. It is extremely important to note that the average percentages do not add up to 100 due to missing topics. The results indicate that on the average, Group 1 institutions cover 37\% quantitative applications, 19\% cases and $15 \%$ global and trade issues in their managerial economics courses. This clearly indicates the importance of these topics. 
Table 4: Distribution of Institutions according to percent coverage of the nature of topics covered in Managerial Economics course in MBA program.

\begin{tabular}{|c|c|c|c|c|c|c|}
\hline \% Coverage & \multicolumn{2}{|c|}{ Quantitative } & \multicolumn{2}{c|}{ Cases } & \multicolumn{2}{c|}{ Global \& Trade } \\
\hline & Group1 & Group2 & Group1 & Group2 & Group1 & Group2 \\
\hline $0-20$ & 20 & 5 & 44 & 9 & 53 & 10 \\
\hline $21-40$ & 19 & 3 & 18 & 2 & 10 & 2 \\
\hline $41-60$ & 15 & 2 & 4 & 2 & 4 & 0 \\
\hline $61-80$ & 10 & 2 & 1 & 0 & 0 & 0 \\
\hline $81-100$ & 3 & 1 & 0 & 0 & & $*$ \\
\hline Total & $* 67$ & $* 13$ & $* 67$ & $* 13$ & & \\
\hline $\begin{array}{c}\text { Average \% } \\
\text { coverage }\end{array}$ & $\mathbf{3 7}$ & $\mathbf{3 7}$ & $\mathbf{1 9}$ & $\mathbf{1 9}$ & & $\mathbf{1 5}$ \\
\hline
\end{tabular}

*Five institutions in Group 1 and two institutions in Group 2 did not respond to this question.

Based on our survey we strongly recommend a combined introductory economics course to be followed by a three credit managerial economics course for the MBA programs.

\section{Technology Usage}

In Table 5 we present the usage of computer technology in teaching managerial economics course in the MBA programs of the AACSB accredited colleges.

Table 5: Technology Usage

\begin{tabular}{|c|c|c|c|c|}
\hline Software & \multicolumn{2}{|l|}{ Group 1} & Group 2 & \\
\hline None & 37 & 51 & 10 & 67 \\
\hline Excel & 26 & 36 & 3 & 20 \\
\hline SPSS & 3 & 4 & 0 & 0 \\
\hline SAS & 2 & 3 & 0 & 0 \\
\hline $\begin{array}{c}\text { Lotus notes, LIMDEP, Data Disk, } \\
\text { Bank Simulator etc }\end{array}$ & 13 & 18 & 2 & 13 \\
\hline
\end{tabular}

Note: Some of the semester based institutions use more than one software packages. Hence the total number of institutions adds up to more than 72 in Group 1.

From Table 5 above we can see that more than 50\% of Group 1 and Group 2 institutions do not use any computer software in teaching managerial economics course. A majority of those that utilize computer software use Excel in their courses

\section{Other Survey Results}

Majority of the AACSB institutions do not waive or substitute managerial economics course at the MBA level, even with prior managerial economics course work at the undergraduate level. More specifically, only four out of 72 semester based institutions offer substitutions and seven out of 72 waive the course.

Suggested topics in a in a semester based course in managerial economics include:

- $\quad$ Optimization ( Profit maximization and Cost minimization)

- $\quad$ Demand Estimation and Forecasting

- $\quad$ Production function and cost estimation

- $\quad$ Pricing Strategies in different market structures

- Government regulations 
- $\quad$ Evaluation of competitive strategies

- $\quad$ Organization of the firms and industry, including ethical issues

- $\quad$ Principles of International Trade, Balance of payments and World Trade Organization

Our analysis also suggests that there is no uniform topical coverage in managerial economics course across the number of MBA programs. In fact, we have some cases where there is significant variation in the subject matter in the same course offered in the same institution. In view of lack of uniformity, we believe that this study will be a useful guide for the offering of managerial economics course in MBA programs.

\section{SECTION III}

Here we present an example in managerial economics area where alternatives to calculus are employed. This is necessitated by the fact that some MBA programs, including our own, do not require calculus as a prerequisite for the core.

Example to illustrate computation of price elasticity of Demand:

Price elasticity of demand is calculated in the following Table 6, using the definition

$E_{P}=\frac{\Delta Q}{Q} \div \frac{\Delta P}{P}=\frac{P}{Q} \times \frac{\Delta Q}{\Delta P}$ where $Q=400-4 P$. Here $Q$ represents quantity demanded, $P$ represents price and $\Delta$

represents a change. We use the demand equation to produce the demand schedule and compute point elasticity (Keating and Wilson, 1992)

Table 6

\begin{tabular}{|c|c|c|}
\hline$P$ in \$ & $Q$ in units & Point elasticity* $-4 \times \frac{P}{Q}$ \\
\hline 90 & & -9.00 \\
\hline 70 & 40 & -2.33 \\
\hline 50 & 120 & -1.00 \\
\hline 30 & 200 & -0.43 \\
\hline 10 & 280 & -0.11 \\
\hline
\end{tabular}

*To show $\frac{\Delta Q}{\Delta P}=-4$, consider the demand function, $Q=400-4 P$, at points 1 and 2 , then

$$
\begin{aligned}
& Q_{1}=400-4 P_{1} \\
& Q_{2}=400-4 P_{2}
\end{aligned}
$$

Subtracting $\quad Q_{1}-Q_{2}=-4\left(P_{1}-P_{2}\right)$

And $\quad \frac{Q_{1}-Q_{2}}{P_{1}-P_{2}}=\frac{\Delta Q}{\Delta P}=-4$

Although we have presented an example above without the use of calculus, one has to view this as only highly limited in scope and is an approximation. Similar examples can be worked out in the area of optimization (maximization of profit or minimization of cost) of economic functions also without the use of calculus. 


\section{SECTION IV: SUMMARY AND CONCLUSION}

We have conducted a survey of 275 AACSB institutions, comparable to the University of Hartford, relating to economics course requirements in their MBA programs and the distribution of topics. Based on our survey, we report the main findings, in general:

- More than $50 \%$ of institutions require either macro or micro economics courses or business statistics course as prerequisites for the managerial economics course.

- $\quad$ Both macro and micro economics are required as prerequisites by $53 \%$ of the institutions.

- $\quad$ Calculus is still required as a prerequisite by more than $40 \%$ of the institutions.

- On the average macro, micro and managerial economics components constitute $18 \%, 28 \%$ and $52 \%$ respectively, of the managerial economics courses.

- $\quad$ A majority of the institutions $(65 \%)$ require more than one economics course.

- On the average institutions cover $37 \%$ quantitative applications, $19 \%$ cases and $15 \%$ global and trade issues in their managerial economics courses.

- More than $50 \%$ of institutions do not use any computer software in teaching managerial economics course and of those that use computer software a majority use Excel in their courses.

- A majority of the AACSB institutions do not waive or substitute managerial economics course at the MBA level, even with prior managerial economics course work at the undergraduate level.

Although managerial economics is a required course in almost all the MBA programs, its contents and the delivery style vary significantly from one institution to another. In fact, even in the same program, it is not uncommon for instructors to follow different topical outlines and textbooks. This is mainly due to the variation on the requirements of introduction to economics and calculus as prerequisites among these programs.

Based on our analysis, we conclude that it is essential to require, at least, a two-course sequence in economics, an introductory combined macro and micro economics as a prerequisite course and a managerial economics course in the core of the MBA programs. It is extremely difficult to cover the principles of economics, both micro and macro and the managerial economics topics, all in one semester required course.

\section{BIBLIOGRAPHY}

1. Anderson, David R., Sweeney Dennis J and Williams Thomas A., An Introduction to Management Science, $8^{\text {th }}$ Edition, St. Paul, Minnesota: West Publishing Co., 1994.

2. Furnham, Paul G. How is Managerial/ Microeconomics being taught: Preliminary Survey Results. Paper presented at the Southern Economics Association Meetings, Orlando, Florida, Nov. 19, 1989.

3. Keating, Barry and Wilson, J. Holton, Managerial Economics, $2^{\text {nd }}$ edition. Orlando, Florida: Harcourt Brace Jovanovich, Inc, 1992.

4. Kolluri, B. R. and Singamsetti Rao, Introduction to Quantitative Methods in Business. A new course without Calculus, Global Business and Technology Association, Emerging Global Issues in the Next Millennium, an International Conference, Montego Bay, Jamaica, West Indies, April 1-4, 1999. (Refereed Proceeding Volume,1999)

5. $\quad$---------, Teaching Economics to MBA students at the University of Hartford, Paper presented at the Economics and the Classroom Conference, Pocatello, Idaho March 30 - April 1, 2000.

6. --------, Summer 2000 Grant Report on Teaching Managerial Economics for MBA Students at the University of Hartford, Barney School of Business, University of Hartford, June 30, 2001.

7. Rose, Elizabeth, Joseph A Marchak and W. Allen Spivey, A Survey of the Teaching Statistics in MBA programs. Journal of Business \& Economic Statistics, April 1988, Vol. 6 No. 2 PP 273-282. 


\section{APPENDIX A}

Date: 22nd January 2001

Dear Dean ...........

We are conducting a survey regarding Managerial Economics course offered in MBA Program in AACSB accredited colleges. We are looking for information regarding prerequisites, if any, the topical coverage, emphasis on computer and quantitative applications and others. We plan to use the results of the survey to propose a common Managerial Economics course and present it as a paper at one of the conferences.

We appreciate your cooperation if you forward the enclosed survey questionnaire to the appropriate faculty members. We will be glad to send the paper upon completion to the concerned faculty members, if desired.

With regards,

Bharat Kolluri.

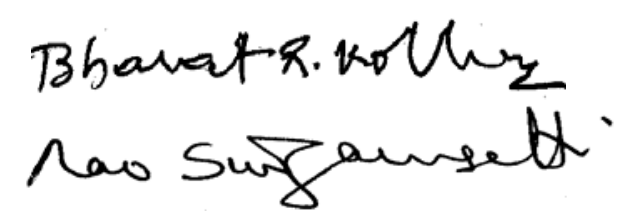

Rao Singamsetti

(Encl: Questionnaire) 


\section{APPENDIX B}

\section{MBA Questionnaire}

1) Is Managerial Economics in your MBA program a semester $\left(\_\right.$) or a quarter $(\square)$ course?

2) a) Are there any prerequisites to Managerial Economics course? Yes

No

b) If the answer to the above is yes, check one or more of the prerequisites.

i) _. Algebra

ii) Pre-calculus

iii) Calculus

iv) Business Statistics

v) Micro Economics Principles

vi) _ Macro Economics Principles

vii) _ Other (Specify)

3) Is Managerial Economics course 3 credit hours course: Yes_ No_

If the answer to the above is no, indicate the number of credit hours. Cr. Hrs

4) Indicate the percent (\%) coverage for each of the following areas in Managerial Economics course

i) Macro Economics Principles

ii) Micro Economics Principles

iii) Managerial Economics

5) Indicate approximately what percent (\%) of each of the following topics is covered.

i) Quantitative application

ii) Case studies

iii) Global and Trade issues

6) a) Do you use any computer software package in your course: Yes_ No_

b) If yes, please provide the names of the software packages.

c) Do you require the students to use computer software package in your course? Yes __ No

7) Does your MBA program require any other economics course in addition to Managerial Economics? Yes__ No

If the answer to the above is yes, please provide the names of the courses

8) Do you waive the managerial economics course for students with prior background in micro and macro principles only? Yes__ No

9) Do you waive the managerial economics course for students who have taken managerial economics course in their undergraduate program?

Yes__, No _, Substitution

NB: please, enclose a copy of the Managerial Economics course syllabus you have recently taught along with the completed survey and mail it in the self addressed and stamped envelope. Thanks. 